\title{
Study on Evaluation System of Crop Variety Comprehensive Value Index
}

\author{
Cao Chengzong \\ Institute of Agricultural Information and Economics, \\ Beijing Academy of Agricultural and Forestry Sciences, \\ Beijing 100097, China \\ jingxcao@qq.com
}

\author{
Chen Junhong ${ }^{1,2 *}$ \\ ${ }^{1}$ Institute of Agricultural Information and Economics, \\ Beijing Academy of Agricultural and Forestry Sciences, \\ Beijing 100097, China \\ ${ }^{2}$ Key Laboratory of urban Agriculture (North China), \\ Ministry of Agriculture, Beijing 100097, China \\ chenjunhong559@163.com
}

\author{
Yang Wei \\ Institute of economics and management BUCT \\ Beijing Intellectual Property Research Base \\ Beijing 100029, China \\ yangwei0430@126.com
}

\begin{abstract}
Scientific assessment items for Crop Variety Comprehensive Value are very important to promote the transformation of agricultural scientific research, enhance the ability of science and technology innovation, and promote seed industry system reform. The evaluation index system of comprehensive value of crop variety rights was established by the combination method of economics and agronomy, from four aspects of law, economy, technology and society. Based on this, the system was used in evaluating the value of two kinds of common maize varieties. The result showed that, this system was an important basis for the selection crop varieties with promotion value and application prospect. It was also an effective tool to evaluate the value of the right of the goods in the transaction.
\end{abstract}

Keywords-Crop; variety right; comprehensive value; Index

\section{INTRODUCTION}

To carry out the evaluation of intellectual property rights of seed industry is an important link to promote the effective application of seed industry scientific and technological achievements and to promote the initiative enthusiasm of scientific research workers. Crop variety rights are intangible assets, and their seed characteristics are affected by many factors, such as technical conditions, natural environment, market competition environment, and so on. It is difficult to evaluate the seed quality accurately.[1-2] This study is based on the research of transaction demand of breeders, entrepreneurs and other varieties of stakeholders. Using agricultural economics and agronomy relevant theories and methods, on the basis of explaining the value of the species rights of farm commodities, the comprehensive evaluation index system of crop variety rights were constructed. Using ordinary corn varieties as an example, the target value and calculation methods were determined. And two kinds of common maize varieties were selected out, using the index system to carry out the variety rights value assessment and results analysis, to verify the index system operability and effectiveness.

\section{The Connotation OF The VALUe OF CROP VARIETY RIGHTS}

The value of crop variety rights means the value and profitability that would be generated by assessing the base date to the end of its rights. It is usually consist of the economic value, social value, academic value, legal value, ecological value and so on[3-4]. Among them, the economic value refers to the crop variety rights as a kind of intellectual property in the technology market transactions directly obtains economic benefits. It is usually determined by these factors, such as market supply and demand, other similar crop varieties of market competition, frequent natural disasters, regional environmental factors[5-6]. Non-economic value, such as technical value, social value and legal value, is the bearing of crop variety right and the potential social and economic benefits caused by commodity transaction. At present, most of the non-economic value evaluation of achievement value is based on qualitative evaluation methods such as investigation, case analysis, peer review and so on[7-9].

\section{CONSTRUCTION OF COMPREHENSIVE EVALUATION INDEX SYSTEM OF CROP VARIETY RIGHTS}

\section{A. Theoretical model}

According to the four aspects of the value of the variety rights, the Value (Crop Variety Comprehensive Indicator) (CVCVI) model was constructed at first,

$$
C V C V I=W_{1} P_{1}+W_{2} P_{2}+W_{3} P_{3}+W_{4} P_{4}
$$

In the equation, CVCVI means Crop Variety Comprehensive Value Indicator; Wi represents the weights of 
the $i$-th level 1 evaluation indicator; $P i$ stands for the factor index of the $i$-th dimension.

In this research, $P_{1}, P_{2}, P_{3}$ and $P_{4}$ represent legal value, economic value, technical value and social value respectively.

Among them,

$$
P_{i}=\sum_{i=1}^{n} \omega_{i} s_{i}
$$

$S_{i}$ represents the degree of realization of each specific evaluation index in each dimension; $\omega_{i}$ represents the weight of the specific indicator.

\section{B. Determination of index weight}

The index weight vector reveals the importance of each indicator in crop variety rights value and their correlation. The same level index is used in determining the weight, the same level indicators are compared, and the relative weights are given according to the importance; the product of the relative weights of each index is used as the absolute weight of the last grade index.

\section{Index calculation method and data source}

The calculation of each index value mainly adopts the combination of the layer difference method and the formula method. The qualitative judgment and objective judgment are carried out through subjective judgment, and the quantitative evaluation is carried out according to the formula. The first is qualitative evaluation. On the basis of analyzing the index characteristics, the evaluation level is divided, and the scores are given to each level. The evaluation indexes are divided into 5 (or 3) levels, which are assigned different scores, with a score of 2 10, a minimum score of 2 , and a maximum score of 10. The second is quantitative evaluation. According to the crop variety standard, the maximum value, reference value and minimum value of the index are determined, and the difference between the present value and the reference value and the product of the coefficient are calculated. The evaluated indexes are divided into layers, and the scores at each level are calculated according to the formula given.

The score is between $0 \sim 10$, that means $0 \leq \mathrm{CVCVI} \leq 10$. The higher the score value is, the higher the comprehensive value of the crop, the better the market prospect, compared with the similar crops. On the contrary, it shows that the crop could not go beyond the existing varieties, and the comprehensive value is not high. The relevant data of crop varieties are evaluated, using regional test results, crop variety techniques and economic information. Since the identification of new species is professional, professionals should be invited to participate in the evaluation.

\section{CONSTRUCtion of VAlue EVAluation IndeX OF CROP VARIETY RIGHTS}

According to the connotation of crop variety rights value, follow the principles of scientific, objective, independent setting and practical index, "comprehensive value index of crop variety rights" was established, including three levels, 4 first level indicators, two level indicators 8, three level indicators 18.

\section{A. Legal value}

The new variety right belongs to the intellectual property protection category; therefore the legal value is its important value constitution attribute. The index mainly refers to whether the evaluated varieties had obtained new plant variety rights and whether they had passed the crop variety approval (or registration of varieties). It has one two-level-indicators, "legal status". And it has two three-level indicators, "new species rights status" and "examination and approval (Registration)".

\section{B. Economic value}

Economic value is the most important embodiment of the right of new breed. Market trading prices are usually influenced by market size, competitors' status, policy orientation, economic life and other factors. Therefore, the first level indicators "economic value", has "market environment" and "economic life" two two-level indicators.

(1) Market environment. It is the factor that directly affects the price of the breed. Indicators include the "expected market size", "market share", "market competition risk" three threelevel indicators.

(2) Economic life time. It is the wholly time experienced from crop new varieties putting on the market to being eliminated. The remaining economic life time has the greatest impact on value, the longer the remaining economic life, the longer the income period, the higher the value of the corresponding. Under the "surplus economic life time", there is one three level indicators.

\section{Technical value}

The technical value is mainly to evaluate the production characteristics and quality characteristics in the actual production of new crop varieties, and this technical index would directly affect the economic benefits of seed production enterprises. The index consists of two two-level indexes: "production characteristics" and "quality characteristics".

(1) Production characteristics. The characteristics of production mainly refer to the requirements of new technology in the process of production, the adaptability to modern largescale mechanization production and the difficulty of seed production. The index consists of three three-level indexes: the technical difficulty of matching, the adaptability of mechanized production and the difficulty of seed production.

(2) Variety characteristics. New varieties of crops, suitable range, yield and stability, adverse environmental resistance and growth period are the main technical indicators to evaluate the value of new varieties. The index has five three level indexes: applicable area range, high yield and stable yield, quality characteristic, resistance and growth period. 


\section{Social value}

Social value mainly evaluates the influence of crop variety extension on national strategy implementation, seed science research development and ecological environment protection.

(1) Abroad promotion. It reflects the application of new crop varieties in foreign countries, including the number of seed producing countries, foreign demonstration areas and so on, is the evaluation of new crop varieties, foreign planting adaptability and their impact on foreign agricultural production. The index consists of two three indicators, "abroad seed production" and " abroad promotion area"

(2) Scientific influence. It reflects the innovation, progress, contribution to the development of science and technology and academic influence of this breeding work. The better the genetic characteristics are, the closer to the forefront of science, the more developed and promoted the value of this species is. The index has a three level index: "germplasm conservation".

(3) Environmental impact. The characteristics of varieties and their effects on regional biodiversity and ecological environment after crop releasing are the contribution of new crop varieties to environmental protection. This indicator contains a three level indicator of "resource consumption".

TABLE I. COMPREHENSIVE EVALUATION INDEX SYSTEM OF CROP VARIETY RIGHTS

\begin{tabular}{|c|c|c|c|}
\hline & $\begin{array}{c}\text { First level } \\
\text { index }\end{array}$ & Two level index & Three level index \\
\hline \multirow{18}{*}{$\begin{array}{l}\text { Synthetic } \\
\text { value } \\
\text { evaluation } \\
\text { system of } \\
\text { variety rights }\end{array}$} & 1. Legal value & 1.1 Legal state & $\begin{array}{l}\text { 1.1.1 New variety } \\
\text { rights } \\
\text { 1.1.2 Examination } \\
\text { and approval } \\
\text { (Registration) }\end{array}$ \\
\hline & & $\begin{array}{l}\text { 2.1 Market } \\
\text { capability }\end{array}$ & $\begin{array}{l}\text { 2.1.1 Expected } \\
\text { market size }\end{array}$ \\
\hline & $\begin{array}{l}\text { 2. Economic } \\
\text { value }\end{array}$ & & $\begin{array}{l}\text { 2.1.2 Market share } \\
\text { 2.1.3 Market } \\
\text { competition risk }\end{array}$ \\
\hline & & $\begin{array}{l}2.2 \text { Economic life } \\
\text { time }\end{array}$ & \\
\hline & & & $\begin{array}{l}\text { 3.1.1 Matching } \\
\text { technical difficulty } \\
\text { 3.1.2 Adaptability }\end{array}$ \\
\hline & & $\begin{array}{l}\text { 3.1 Production } \\
\text { characteristics }\end{array}$ & \\
\hline & & & $\begin{array}{l}\text { 3.1.3 Seed } \\
\text { production }\end{array}$ \\
\hline & 3. Technical & & difficulty \\
\hline & value & & \\
\hline & & & $\begin{array}{l}\text { 3.2.2 High and } \\
\text { stable yield }\end{array}$ \\
\hline & & 3.2 Variety & 3.2.3 quality \\
\hline & & & $\begin{array}{l}\text { 3.2.4 Stress } \\
\text { resistance }\end{array}$ \\
\hline & & & $\begin{array}{l}3.2 .5 \text { growth } \\
\text { period }\end{array}$ \\
\hline & 4. Social value & $\begin{array}{l}\text { 4.1 Abroad } \\
\text { promotion }\end{array}$ & $\begin{array}{l}\text { 4.1.1 Abroad seed } \\
\text { production } \\
\text { 4.1.2 Abroad } \\
\text { promotion area }\end{array}$ \\
\hline & & 4.2 Scientific & 4.2.1 Germplasm \\
\hline & & influence & conservation \\
\hline & & 4.3 Environmental & $\begin{array}{l}\text { 4.3.1 Resource } \\
\text { consumption }\end{array}$ \\
\hline & & 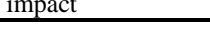 & consumption \\
\hline
\end{tabular}

\section{Determination of TARget VAlue of Corn VARIETy RighTS EVALUATION INDEX}

In general, different varieties of maize have different varietal characteristics. Taking the largest amount of corn in the market as an example, the target value of the evaluation index of corn variety rights is determined. Two kinds of corn variety, A and B are selected out, according to the above model and weight determination method, their variety rights are evaluated and verified.

\section{A. Qualitative evaluation index}

For the indexes which are difficult to be quantified, the experts divide three or five levels according to the index state characteristics of the evaluated crop varieties, and assign different values respectively.

The four indexes, new variety rights, variety approval (Registration), conservation of germplasm resources and consumption of resources, are divided into 3 grades to evaluate according to the degree of completion, which are given 10, 6 and 2 respectively. Specific standards are shown in table 2 .

TABLE II. THREE LAYERS SCORING SYSTEM OF CORN VARIETY RIGHTS VALUE (QUALITATIVE PART)

\begin{tabular}{|c|c|c|c|}
\hline $\begin{array}{c}\text { Scoring } \\
\text { standard }\end{array}$ & 10 & 6 & 2 \\
\hline $\begin{array}{l}\text { New variety } \\
\text { rights status }\end{array}$ & $\begin{array}{l}\text { New variety } \\
\text { rights have } \\
\text { been } \\
\text { obtained }\end{array}$ & $\begin{array}{l}\text { New variety rights have } \\
\text { been submitted and } \\
\text { rights certificates have } \\
\text { not been obtained }\end{array}$ & $\begin{array}{l}\text { New plant } \\
\text { species rights } \\
\text { claims have not } \\
\text { yet been filed } \\
\text { The }\end{array}$ \\
\hline $\begin{array}{l}\text { Variety } \\
\text { approval } \\
\text { (Registration) }\end{array}$ & $\begin{array}{l}\text { Has been } \\
\text { approved by } \\
\text { major crop } \\
\text { varieties }\end{array}$ & $\begin{array}{l}\text { Major crop varieties } \\
\text { have not yet been } \\
\text { examined and } \\
\text { approved, but they have } \\
\text { reached the standards } \\
\text { of maize approval (all } \\
\text { the data are available) }\end{array}$ & $\begin{array}{l}\text { varieties have } \\
\text { not been } \\
\text { examined and } \\
\text { approved yet, } \\
\text { and the } \\
\text { information has } \\
\text { not been } \\
\text { prepared yet }\end{array}$ \\
\hline $\begin{array}{l}\text { Germplasm } \\
\text { conservation }\end{array}$ & $\begin{array}{l}\text { great } \\
\text { significance } \\
\text { to enrich } \\
\text { Germplasm } \\
\text { Resources }\end{array}$ & $\begin{array}{l}\text { certain significance to } \\
\text { enrich Germplasm } \\
\text { Resources }\end{array}$ & $\begin{array}{l}\text { little } \\
\text { significance to } \\
\text { enrich } \\
\text { Germplasm } \\
\text { Resources }\end{array}$ \\
\hline $\begin{array}{l}\text { Resource } \\
\text { depletion } \\
\text { (S31) }\end{array}$ & $\begin{array}{l}\text { Pesticide, } \\
\text { fertilizer } \\
\text { and other } \\
\text { factors } \\
\text { decreased } \\
\text { significantly }\end{array}$ & $\begin{array}{l}\text { Pesticide, fertilizer and } \\
\text { other factors decreased } \\
\text { certainly }\end{array}$ & $\begin{array}{l}\text { Pesticide, } \\
\text { fertilizer and } \\
\text { other factors are } \\
\text { basically not } \\
\text { reduced }\end{array}$ \\
\hline
\end{tabular}

The expected market size, market share, market competition risk, remaining economic life, matching technical difficulty, seed production difficulty, application scope, abroad seed production, abroad promotion area, these 9 indexes according to their own performance are divided into 5 grades, which are assigned 10, 8, 6, 4 and 2 respectively. Specific standards are shown in table 3. 
TABLE III. FIVE LAYERS SCORING SYSTEM OF CORN VARIETY RIGHTS VALUE (QUALITATIVE PART)

\begin{tabular}{|c|c|c|c|c|c|}
\hline & 10 & 8 & 6 & 4 & 2 \\
\hline $\begin{array}{l}\text { Expected } \\
\text { market size } \\
\text { (Sown area) }\end{array}$ & huge & large & moderate & small & very small \\
\hline Market share & $>80 \%$ & $60 \%-79 \%$ & $40 \%-59 \%$ & $10 \%-39 \%$ & $<10 \%$ \\
\hline $\begin{array}{l}\text { market } \\
\text { competition } \\
\text { risk }\end{array}$ & $\begin{array}{l}\text { Few } \\
\text { competitors }\end{array}$ & $\begin{array}{l}\text { weaker } \\
\text { competitors }\end{array}$ & $\begin{array}{l}\text { generally } \\
\text { Competitors }\end{array}$ & $\begin{array}{l}\text { Strong } \\
\text { competitors }\end{array}$ & $\begin{array}{l}\text { Unbeatable } \\
\text { competitors }\end{array}$ \\
\hline $\begin{array}{l}\text { Remaining } \\
\text { economic life }\end{array}$ & $>$ 10years & 8-9 years & $6-7$ years & $4-5$ years & $1-3$ years \\
\hline $\begin{array}{l}\text { Matching } \\
\text { technical } \\
\text { difficulty }\end{array}$ & $\begin{array}{l}\text { Fully adapted } \\
\text { to existing } \\
\text { conventional } \\
\text { technology }\end{array}$ & $\begin{array}{l}\text { Adapt to the } \\
\text { existing } \\
\text { conventional } \\
\text { production } \\
\text { technology }\end{array}$ & $\begin{array}{l}\text { Basically fit } \\
\text { most existing } \\
\text { production } \\
\text { technologies }\end{array}$ & $\begin{array}{l}\text { need } \\
\text { specialized } \\
\text { sproduction } \\
\text { techniques, } \\
\text { easy to } \\
\text { master }\end{array}$ & $\begin{array}{l}\text { need } \\
\text { specialized } \\
\text { production } \\
\text { techniques, } \\
\text { difficult to } \\
\text { master }\end{array}$ \\
\hline $\begin{array}{l}\text { Seed } \\
\text { production } \\
\text { difficulty }\end{array}$ & very easy & $\begin{array}{l}\text { relatively } \\
\text { easy }\end{array}$ & $\begin{array}{l}\text { a little } \\
\text { difficult }\end{array}$ & difficult & very difficult \\
\hline $\begin{array}{l}\text { Application } \\
\text { scope }\end{array}$ & $\begin{array}{l}\text { Suitable for } 3 \\
\text { ecological } \\
\text { regions }\end{array}$ & $\begin{array}{l}\text { Suitable for } 2 \\
\text { ecological } \\
\text { regions }\end{array}$ & $\begin{array}{l}\text { Suitable for } 1 \\
\text { ecological } \\
\text { regions }\end{array}$ & $\begin{array}{l}\text { Suitable for a } \\
\text { particular } \\
\text { environment } \\
\text { in } 1 \\
\text { Ecological } \\
\text { Zones }\end{array}$ & $\begin{array}{l}\text { Suitable for a } \\
\text { particular } \\
\text { range of } 1 \\
\text { Ecological } \\
\text { Zones }\end{array}$ \\
\hline $\begin{array}{l}\text { Abroad seed } \\
\text { production } \\
\text { (number of } \\
\text { breeding } \\
\text { countries) }\end{array}$ & 0 & 1 & 2 & 3 & $>3$ \\
\hline $\begin{array}{l}\text { Abroad } \\
\text { Promotion } \\
\text { area (sown } \\
\text { area) }\end{array}$ & huge & large & moderate & small & very small \\
\hline
\end{tabular}

\section{B. Quantitative evaluation index}

Quantitative evaluation is mainly used in determining the value of technical indicators, using objective data and calculation formula, as far as possible scientific and detailed distinction between different varieties of technical indicators. Five indexes, such as adaptability, high and stable yield, quality characteristics, stress resistance and growth period, are evaluated quantitatively by means of reference value and formula method. For the benchmark value, priority should be given to the current national standards on the approval of new varieties. Otherwise, it should be based on the experience of the experts in the breeding industry.

(1) Mechanization production adaptability. The suitability of mechanized production could be well suited to mechanization and large-scale production, mainly to calculate the sum of lodging rates. The specific evaluation method, the crop varieties in the production process of mechanization, large-scale production of adaptation (lodging and folding) is divided into five levels, and are given different scores or formula, score between $0 \sim 10$ points, the lowest 0 points, the highest 10 points. The standard and the base value and the highest value are determined mainly by the Ministry of agriculture's "measures for approving major crop varieties (2014)" and the opinions of agricultural experts. The formula is shown in the table 4.
TABLE IV. INDEX OF ADAPTABILITY INDEX FOR MECHANIZED PRODUCTION OF COMMON MAIZE VARIETIES

\begin{tabular}{|c|c|c|c|c|}
\hline \multirow{3}{*}{$\begin{array}{l}\text { Non mechanized } \\
\text { harvesting } \\
\text { Score }\left(t_{1}\right)\end{array}$} & \multicolumn{4}{|c|}{ The Sum of lodging and folding rates $\left(S_{1}\right)(\%)$} \\
\hline & $\begin{array}{l}\text { Scoring } \\
\text { standard }\end{array} S_{1}=0 \%$ & $S_{1}<8 \%$ & $S_{1}=8 \% 8 \%<S_{1}<16 \%$ & $S_{1} \geq 16 \%$ \\
\hline & 10 & $t_{1}=6+\left(8-S_{1}\right) \times 0.5$ & $t_{1}=6-\left(S_{1}-8\right) \times 0.75$ & 0 \\
\hline $\begin{array}{l}\text { Suitable for } \\
\text { Mechanized } \\
\text { harvesting }\end{array}$ & $\begin{array}{l}\text { Scoring } \\
\text { standard }\end{array} S_{1}=0 \%$ & $S_{1}<3 \%$ & $S_{1}=3 \% 3 \%<S_{1}<8 \%$ & $S_{1} \geq 8 \%$ \\
\hline Score $\left(t_{1}\right)$ & 10 & $t_{1}=6+\left(3-S_{1}\right) \times 4 / 36$ & $t_{1}=6-\left(S_{1}-3\right) \times 1.2$ & 0 \\
\hline
\end{tabular}

(2) High yield and stable yield. This index is used in evaluating the yield per unit area and stability of crops harvested. The annual crop trials and yield of the evaluated crop varieties are divided into four levels, which are different from those of the control varieties (compared with the yield increase of the control varieties), and are given different scores respectively. Because of the difference of biological characteristics of various varieties, the reference value and coefficient in the formula is varying according to the variety and classification of crops. The table 5 below is for the assessment year maize varieties regional test and production test yield than the control varieties percentage increase in actual production, the reference value is based on the "Key crop variety validation standard (2014)" and the agricultural experts production experience data.

TABLE V. SCORING STANDARD OF HIGH YIELD AND STABLE YIELD INDEX OF COMMON MAIZE

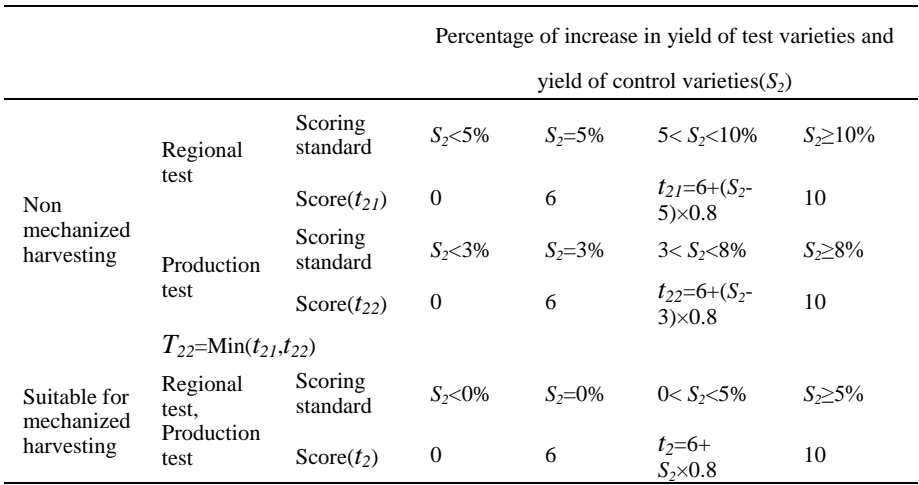

(3) Quality characteristics. It is including sensory quality, nutritional quality, hygiene quality, processing quality, and so on. For the common maize, we evaluate the quality (capacity) of the unit volume of maize. And the evaluation data are determined according to the identification and test results of the designated institutions of the variety approval committee. This index is divided the quality characteristics of the evaluated crop products into five levels and different values are given respectively. (The formula is shown in table 6.) 
TABLE VI. SCORING STANDARD OF COMMON MAIZE QUALITY INDEX

\begin{tabular}{|c|c|c|c|c|}
\hline \multicolumn{3}{|c|}{ Corn dry matter Bulk density $\left(S_{3}\right)$} & \multicolumn{2}{|l|}{ (unit: g / L) } \\
\hline $\begin{array}{c}S_{3}<590 \\
\text { Scoring standard (Substandard } \\
\text { class) }\end{array}$ & $\begin{array}{c}710>S_{3}>590 \\
\text { (Five grade goods) }\end{array}$ & $\begin{array}{c}S_{3}=710 \\
\text { (National standard) }\end{array}$ & $\begin{array}{l}720>S_{3}>710 \\
\text { (First Grade) }\end{array}$ & $S_{3} \geq 720$ \\
\hline Score $\left(t_{3}\right)$ & $t_{3}=6-\left(710-S_{3}\right) \times 0.05$ & 6 & $t_{3}=6+\left(S_{3}-710\right) \times 0.4$ & 10 \\
\hline
\end{tabular}

(4) Stress resistance. Reflect the resistance or tolerance of crop varieties to biotic and abiotic stresses, including resistance to major local diseases, pests, droughts, and poor fertility. The resistance indexes of crop varieties are divided into four levels, and different values are assigned respectively. (The formula is shown in table 7.)

TABLE VII. SCORING STANDARD OF DISEASE RESISTANCE INDEX OF COMMON MAIZE

\begin{tabular}{|c|c|c|c|c|}
\hline \multirow{2}{*}{$\begin{array}{l}\text { Scoring } \\
\text { standard }\end{array}$} & \multicolumn{4}{|c|}{$\begin{array}{l}\text { Average natural incidence rate of common maize in field }\left(S_{4}\right) \\
\text { (unit:\%) }\end{array}$} \\
\hline & $S_{4}=0 \%$ & $0<S_{4}<3 \%$ & $S_{4}=3 \%$ & $S_{4} \geq 3 \%$ \\
\hline $\operatorname{Score}\left(t_{4}\right)$ & 10 & $t_{4}=6+\left(3-S_{4}\right) \times 4 / 3$ & 6 & 0 \\
\hline
\end{tabular}

(5) Growth period. In the process of evaluation, the gap between the growth period and the control varieties is used in indicating the different between the two. The gap of growth period is divided into four levels, and different scores or calculation methods are assigned respectively. The baseline value is the growth period gap (late maturity) for 2 days (or 3 days). (The formula is shown in table 8.)

TABLE VIII. SCORING STANDARD OF GROWTH PERIOD INDEX FOR COMMON MAIZE

\begin{tabular}{|c|c|c|c|c|c|}
\hline \multicolumn{6}{|c|}{$\begin{array}{l}\text { late maturing days of the maize variety than those of the control variety }\left(S_{5}\right) \\
\text { Unit: days }\end{array}$} \\
\hline $\begin{array}{l}\text { Northeast \& North China } \\
\text { spring maize area, northeast } \\
\text { middle maturing spring } \\
\text { maize area, northeast early } \\
\text { spring maize area, very early } \\
\text { spring maize area, northwest } \\
\text { spring maize area, southwest } \\
\text { corn area and Southeast corn } \\
\text { area }\end{array}$ & Evaluation criterion & $S_{5}>2$ & $S_{5}=2$ & $t_{5}=6+\left(2-S_{5}\right) \times 2$ & $S_{5}=0$ \\
\hline $\begin{array}{l}\text { Huang Huai summer } \\
\text { corn area }\end{array}$ & $\begin{array}{l}\text { Evaluation criterion } \\
\text { Score }\left(t_{5}\right)\end{array}$ & $\begin{array}{c}S_{5}>3 \\
0\end{array}$ & $\begin{array}{c}S_{5}=3 \\
6\end{array}$ & $\begin{array}{c}0<S_{5}<3 \\
t_{5}=6+\left(3-S_{5}\right) \times 4 / 3\end{array}$ & $\begin{array}{c}S_{5}=0 \\
10\end{array}$ \\
\hline
\end{tabular}

\section{Evaluation verification}

To test and verify the rationality of the evaluation index system, two kinds of maize varieties in the market are selected out, A\&B, using crop varieties comprehensive value evaluation index system and evaluation model, to calculate and verify the comprehensive value of varieties, the results are shown in table 9.
TABLE IX. COMPREHENSIVE VALUE CALCULATION OF CORN VARIETY A AND VARIETY $B$

\begin{tabular}{|c|c|c|c|c|c|c|c|}
\hline $\begin{array}{l}\text { First level } \\
\text { index }\end{array}$ & Two level index & Three level index & weight & $\begin{array}{l}\text { Evaluation } \\
\text { score of } \\
\text { "A" }\end{array}$ & $\begin{array}{l}\text { Evaluation } \\
\text { score of } \\
\text { "B" }\end{array}$ & $\begin{array}{l}\text { Evaluation } \\
\text { results of } \\
\text { "A" }\end{array}$ & $\begin{array}{c}\text { Evaluation } \\
\text { results of } \\
\text { "B" }\end{array}$ \\
\hline \multirow{3}{*}{$\begin{array}{l}\text { 1. Legal } \\
\text { value }\end{array}$} & \multirow{3}{*}{ Legal state } & New variety rights & 0.05 & 10 & 2 & 0.5 & 0.1 \\
\hline & & $\begin{array}{l}\text { Examination and } \\
\text { approval } \\
\text { (Registration) }\end{array}$ & 0.05 & 10 & 8 & 0.5 & 0.4 \\
\hline & & $\begin{array}{l}\text { Expected market } \\
\text { size }\end{array}$ & 0.10 & 10 & 6 & 1 & 0.6 \\
\hline \multirow{5}{*}{$\begin{array}{l}2 . \\
\text { Economic } \\
\text { value }\end{array}$} & \multirow{2}{*}{ Market capability } & Market share & 0.07 & 8 & 6 & 0.56 & 0.42 \\
\hline & & $\begin{array}{l}\text { Market } \\
\text { competition risk }\end{array}$ & 0.07 & 10 & 2 & 0.7 & 0.14 \\
\hline & \multirow[t]{2}{*}{ Economic life } & $\begin{array}{l}\text { Remaining } \\
\text { economic life }\end{array}$ & 0.11 & 10 & 10 & 1.1 & 1.1 \\
\hline & & $\begin{array}{l}\text { Matching } \\
\text { technical } \\
\text { difficulty }\end{array}$ & 0.07 & 10 & 10 & 0.7 & 0.7 \\
\hline & \multirow{3}{*}{$\begin{array}{l}\text { Production } \\
\text { characteristics }\end{array}$} & $\begin{array}{l}\text { Adaptability of } \\
\text { mechanized } \\
\text { production }\end{array}$ & 0.07 & 10 & 10 & 0.7 & 0.7 \\
\hline \multirow{8}{*}{$\begin{array}{l}3 . \\
\text { Technical } \\
\text { value }\end{array}$} & & $\begin{array}{l}\text { Seed production } \\
\text { difficulty }\end{array}$ & 0.07 & 10 & 10 & 0.7 & 0.7 \\
\hline & & Applicable area & 0.03 & 10 & 10 & 0.3 & 0.3 \\
\hline & \multirow{4}{*}{$\begin{array}{l}\text { Variety } \\
\text { characteristics }\end{array}$} & $\begin{array}{l}\text { High and stable } \\
\text { yield }\end{array}$ & 0.03 & 10 & 6.39 & 0.3 & 0.19 \\
\hline & & quality & 0.04 & 8 & 8 & 0.32 & 0.32 \\
\hline & & Stress resistance & 0.07 & 6 & 6 & 0.42 & 0.42 \\
\hline & & growth period & 0.07 & 10 & 9.988 & 0.7 & 0.70 \\
\hline & \multirow{2}{*}{$\begin{array}{l}\text { Abroad } \\
\text { promotion } \\
\text { situation }\end{array}$} & $\begin{array}{l}\text { Abroad seed } \\
\text { production }\end{array}$ & 0.02 & 0 & 0 & 0 & 0 \\
\hline & & $\begin{array}{l}\text { Abroad promotion } \\
\text { area }\end{array}$ & 0.02 & 0 & 0 & 0 & 0 \\
\hline \multirow{2}{*}{$\begin{array}{l}\text { 4. Social } \\
\text { value }\end{array}$} & $\begin{array}{l}\text { Scientific } \\
\text { influence }\end{array}$ & $\begin{array}{l}\text { Germplasm } \\
\text { conservation }\end{array}$ & 0.03 & 6 & 6 & 0.18 & 0.18 \\
\hline & $\begin{array}{l}\text { Environmental } \\
\text { impact }\end{array}$ & $\begin{array}{l}\text { resource } \\
\text { consumption }\end{array}$ & 0.03 & 2 & 2 & 0.06 & 0.06 \\
\hline \multicolumn{3}{|c|}{ Composite value score } & & & & 8.73 & 7.01 \\
\hline
\end{tabular}

As shown in Table 9, through calculation, the comprehensive value of two crops of A and B has obvious difference, and the scores are 8.73 and 7.01 respectively, and the two kinds of common maize varieties all perform well. The results of evaluation are basically consistent with the two varieties' market value and public cognition.

Compared between the two varieties, the A value of maize variety is higher than that of cultivar B. Variety A is more prominent in legal value, economic value and technical value, while B is only slightly higher than A in social value. Therefore, for the buyers in the trade of crop varieties, priority should be given to the selection of A varieties to obtain greater social and economic benefits.

\section{CONCLUSION AND DISCUSSION}

\section{A. Conclusion}

The evaluation of the total value of variety rights of two corn varieties shows that the evaluation system was feasible and had certain theoretical and practical value.

The evaluation result shows that, the value of technology, value and economic value of the contribution of the value of the total score is higher, the proportion of the two in the total score is more than $86 \%$; technical and economic value are the main aspects of the variety right. The contribution of legal value and social value to total value is less than $14 \%$, which indicates that although the two are important parts of crop variety rights, their contribution to the total value is secondary. Obviously, this conclusion accords with the current value cognition of crop variety rights. 


\section{B. Analysis and discussion}

This study selected core indicators from four levels of law, technology, economy and society, and combines qualitative and quantitative methods. It is a useful attempt to evaluate crop variety value. In order to ensure the scientific nature of the evaluation results, it is suggested that the third party organizations be introduced to enable them to carry out evaluations to ensure that the evaluation results to be more independent, objective and fair.

Of course, in the index system there are still some limitations in: firstly, the representative index selection is reasonable, reflect the academic value of the ecological environment. But, its' sustainable effect and quality of individual special representative indexes need further evaluation; secondly, there are some subjective factors in qualitative evaluation hierarchy and direct evaluation; the third, the selection of benchmark value is specific, distinct varieties and characteristics of phased development of breeding, so it is inevitable to have unreasonable and unscientific places.

It should be pointed out that the value evaluation of crop variety rights is only a means to promote the transformation of achievements in the seed industry development. With the increase of seed industry scientific and technological achievements transaction, the evaluation index system of large data, content analysis and data mining will continue to be used, summarized, adjusted and improved to better guide practice.

\section{ACKNOWLEDGMENT}

This study is funded by the following projects.

1. The condition and platform construction project of Beijing academy of agriculture and forestry sciences, "Rural distance information service engineering technology research center of Beijing"(2017).

2. Foundation Item: The Science and Technology Innovation Team Program of Beijing Academy of Agriculture and Forestry Sciences (JNKST201601)
3. The Science and Technology Innovation ability construction Program of Beijing Academy of Agriculture and Forestry Sciences (KJCX20170507)

\section{REFERENCES}

[1] Chen Huiying, Zhuang Xin, Risks and Countermeasures of plant variety rights pledge financing, J. Journal of Shandong University of Science and Technology (Social Sciences). 2016, (02):67-72+79.(In Chinese)

[2] Ren Jing, Research on the Comprehensive Quality and Value Evaluation of Authorized Plant Variety, D. Chinese Academy of Agricultural Sciences, 2015(In Chinese)

[3] Ren Jing, Song Min, Quality Evaluation Model for New Plant Variety Right based on Logistic Regression--Taking Plant Variety Right of Hybrid Rice as a Case, J. Journal of Agricultural Science and Technology. 2016,18(01) 209-216. (In Chinese)

[4] Lv Xiaorong, An empirical study of patent value evaluation index system and patent technology quality evaluation, J. Scientific and technological progress and Countermeasures, 2014, (20) 113-116. (In Chinese)

[5] He Defang, Discrimination and Reflection on some basic concepts of scientific and technological achievements and transformation of scientific and technological achievements, J. China Soft Science. 2011,(11)1-7. (In Chinese)

[6] Liu Shuqing, Su Qin, Chen Dandan, Research on target market evaluation and selection model of industrialization of scientific and technological achievements, J. Scientific and technological progress and Countermeasures. 2012,(15) 119-125. (In Chinese)

[7] Lu Jingjing, Tan Zongying, Wan Hao, The analysis and thinking about the contents of achievements evaluation of science and technology projects, J. Scientific Management Research. 2016, (01)37-41. (In Chinese)

[8] Wang Jinghua, Zhong Chunyan, Accelerate Transformation of Agricultural Science and Technology to Promote Agricultural Development Mode, J. Agricultural modernization research, 2012 (02) 195-198. (In Chinese)

[9] Zhao Zhiyun, DU Hongliang. Study on the Monitoring Index System for Transformation Process of Scientific and Technical Achievements, J. China Soft Science. 2011, (11) 8-14. (In Chinese) 